\title{
STUDY ON THE IMPACT OF GRID ELECTRICITY IN POWERING THE EXPANSION OF HEALTHCARE SERVICES AND FACILITIES IN SAGAR ISLAND
}

\begin{abstract}
Sagar Island, also known as 'Gangasagar' in commoners' parlance is one of the populous islands that falls under the Sundarban Biosphere Reserve in the State of West Bengal. The Island articulates the faith and sentiments of teeming billions of this country in a transcendental and sublime manner since time immemorial. Despite the age-old religious and cultural connotations, the island's socio-economic growth was contained to a certain extent due to non-availability of grid electricity. Islanders had to depend primarily on energy supplied in an intermittent manner through solar photovoltaic cells, diesel generator sets, kerosene-fed implements used for illumination or otherwise along with fuelwood. Situation in Sagar Island had started changing dramatically from 2012 onwards with the rolling out of 100 per cent household electrification programme under 'Integrated Coastal Zone Management Project.' Resonance of grid electricity is palpable cutting across all geographic, social and economic heterogeneities in Sagar Island. The execution of the entire component did have a kaleidoscopic impact through spurting of multiple socio-economic activities in Sagar Island. The present paper deliberates on the impact of grid electricity vis-à-vis the improvements that have taken place with respect to healthcare services and facilities in Sagar Island. The study shows that the initiatives, that are propelled either due to distribution of grid electricity through government-owned healthcare centres or through private healthcare enterprises, are quite impressive. Quantitative and qualitative assessments of 17 units, instrumental in providing healthcare services and facilities of varied nature in Sagar Island, have proved beyond doubt that grid electricity is not only a demand-driven project initiative whence it was conceived but in real terms is a game-changer that accelerates the pace of sustainable development.
\end{abstract}

\footnotetext{
*Documentation Officer, India Integrated Coastal Zone Management Project (Assisted by the World Bank), SPMU- West Bengal, Institute of Environmental Studies \& Wetland Management, Department of Environment, Government of West Bengal, E-Mail: surchayan1@gmail.com

The author wishes to thank interviewees of Sagar Island and Dr. Tandra Ghosh, Associate Professor Tripura Medical College and Shri Amitava Swarnakar, Project Assistant, ICZMP - West Bengal for the help and support during the study.
}

Journal of Rural Development, Vol. 36, No. 3, July-September : 2017 


\section{Introduction}

Sagar Island is located in the GangesBrahmaputra delta and lies at the mouth of the river Hooghly. Since time immemorial, the Island is drenched with the mythological mysticism of Sankhya philosophy of sage Kapil Muni that reverberates from this landmass with high amplitude, especially during 'Gangasagar Mela' - the annual religious congregation that happens each year at the time of Makar Sankranti (either 14 or 15, January) where millions from all over India do swarm in to pay their obeisance and homage to the deity Ganga and sage Kapil. Sagar block that comes under the administrative jurisdiction of South 24 Parganas district in West Bengal consists of Sagar Island and Ghoramara Island. Sagar Island also falls under Sundarban Biosphere Reserve and is totally cut-off from the mainland by Muriganga river. The total geographical area of the Sagar block is 282.11 sq. km. Apart from the religio-cultural significance of the Island, it is also considered to be one of the populous and large islands of the Indian nation State. According to 2011 Census of Government of India, the population of Sagar block was 2,12,037 and the number of households was 43,716 .

The economic development of the Sagar block was constrained to a large extent not only due to absence of direct road/railway linkages with the mainland but also due to non-existence of $24 \times 7$ grid power. Till 201011 around 220 households housing 2,178 people and 394 commercial consumers were provided with electrical power from Diesel
Generator (DG) sets for four hours daily by West Bengal State Electricity Distribution Corporation Limited (WBSEDCL). Some of the rural households drew power from solar photovoltaic power plants operated through West Bengal Renewable Energy Development Agency (WBREDA) in a limited scale. Both the previously mentioned public sector utilities come under the Department of Power and Non-conventional Energy Sources, Government of West Bengal.

In this backdrop in mid-2011, Integrated Coastal Zone Management Project (ICZMP) assisted by the World Bank had started rolling out in the State of West Bengal and one of its project components was to provide grid power to the Sagar Island for ushering in the spirit of sustainable development. The project component entitled as '100 per cent Household Electrification in Sagar Island' was conceived to provide grid-fed energy which would eventually bring tangible changes in the basic architecture of the scheme of socio-economic relationships that exist through the promotion and facilitation of grid power dependent livelihood options. This project component, as envisaged, not only had intended to improve the quality of life in macro, meso and micro levels of the coastal community but also to steer the process of environmental amelioration by way of phasing out the fossil fuel ravening Diesel Generator (DG) sets - which acted as a major contributory factor for the proliferation of air and noise pollution in Sagar Island. Even though the distribution of grid electricity has already brought some visible changes in the 
quality of life and livelihood options of the residents of Sagar Island, the present paper only delves into the impact of grid electricity as a catalyst for improving the condition of healthcare services and facilities in the Island.

\section{An Overview of ICZM Project}

The Ministry of Environment, Forests and Climate Change (MOEF\&CC), Government of India, had requested the assistance of the World Bank in 2010 for financing an investment project referred to as 'India: Integrated Coastal Zone Management Project', in order to build national level capacity for having an integrated management approach in the coastal zones of India coupled with (a) mapping, delineation and demarcation of the hazard lines and delineation of the coastal sediment cells (b) mapping, delineation, and demarcation of ecologically sensitive areas which are likely to be affected by climate change and to be classified as 'Critically Vulnerable Coastal Areas' (c) establishing a National Centre for Sustainable Coastal Zone Management to work with coastal communities and advise the MOEF\&CC on policy matters. Apart from national level afore-mentioned project components, ICZMP also finances multiple pilot investments for adopting the integrated coastal zone management approach in three States, e.g., Gujarat, Odisha and West Bengal.

Initially the execution of India ICZM project activities was planned to be carried out from June 2010 to December 2015, but later on, it was extended to December, 2017. The initial total project cost estimate was
₹ 1155.63 crore, in which the West Bengal's allocation was ₹ 300.26 crore. However, with the extension of time duration, revised cost estimate for the entire India ICZM project stands out to be ₹ 1580.07 crore and that of West Bengal's allocation escalates to ₹ 335.62 crore.

The implementation of the West Bengal component is being steered through a special purpose vehicle called the West Bengal State Project Management Unit (SPMU). The Government of West Bengal had created the same in 2010. SPMU is housed at the Institute of Environmental Studies and Wetland Management that functions under the Department of Environment, Government of West Bengal.

West Bengal's component is "aimed at developing and empowering State level authorities to adopt appropriate ICZM approaches, consistent with national strategies; includes several sub-components like (a) preparation and adoption of an ICZM plan for the coastal stretches of West Bengal (b) institutional strengthening and capacity building at the State level; and, (c) pilot investments consistent with local ICZM priorities in the intervened coastal blocks centred around three themes of (i) Conservation and protection of coastal resources; (ii) Environment and pollution management; and (iii) Livelihood security of coastal communities."

At present West Bengal's project components are mainly spread over 7 blocks 
of East Midnapore and 5 blocks of South 24 Parganas districts, respectively. In addition to it, the capacity building and scientific research activities financed through this project component try to target the entire coastal population in its entirety, either directly or indirectly. The SPMU had collaborated with 11 different government departments/ agencies/ corporations / societies referred to as Pilot Investment Executing Agencies (PIEAs) for execution of the project components. Table A in annexure elucidates the work component allocation among the PIEAs and SPMU.

\section{Grid Electricity in Sagar Island}

In order to foster the spirit of inclusive growth at Sagar Island and to enhance the quality of life through augmentation of commercial activities, industrial activities, irrigation facilities, etc., WBSEDCL was assigned the task of rural electrification of Sagar Island under ICZMP. The total financial outlay of this project component was ₹ 34.24 crore. However, the contract signed for the work component was ₹ $32.27 \mathrm{crore}$. The work was commenced in May 2012 and was completed in March 2015.

The scope of work financed from ICZMP is delineated below.

I. Erection of Poles - 30,466 units

II. Stringing of Wires in ckm ( circuit Km) - 1159 ckm

III. Distribution Transformers installed - 595 units
Till date, WBSEDCL has been successful to provide over 31050 service connections (which include both domestic and commercial connections) and that too for $24 \times 7$. The impact of distribution of grid electricity is quite palpable with wide ranging socioeconomic ramifications and in this context the SPMU has embarked on a brief study to analyse the impact of grid electricity vis-à-vis the augmentation of healthcare services and facilities in the Island.

\section{Healthcare System in Sagar Island}

The entire healthcare system in the Island can be dissected into two categories: public and private enterprises. Publicly owned and managed enterprises include a rural block hospital, three primary healthcare centres and 41 primary healthcare sub-centres. Private enterprises facilitating healthcare in the Island include a nursing home, allopathic medical shops, pathological labs, ECG-cum-medical imaging units, physiotherapy centres, ophthalmic-cum-dentistry polyclinics or dispensaries, homeopathic medicine shops and a number of makeshift chambers where medics (unauthorised) provide elementary healthcare services to the coastal community.

\section{Objectives of the Study}

$\checkmark \quad$ To analyse the sources of energy that were put for use before induction of grid electricity;

To study the impact of grid electricity in powering the improvement of the 
healthcare services and facilities in Sagar Island;

Ú To know the quality of services provided by the service provider, e.g., WBSEDCL and the reasons for power cut.

\section{Methodology}

The study, conducted in November 2015 , used a mix of quantitative and qualitative methodologies. The present work considered 17 units associated with the prevailing healthcare system spanning over 8 Gram Panchayats of Sagar Island. Quota sampling has been deployed for identification of the healthcare units in a logical and representative manner so that relevant information can be extracted for interpretation and analysis. It is to be noted that quota sampling provides the flexibility of non-probability equivalent of stratified sampling with a mix of convenient or judgment sampling to select the required number of elements from each stratum in a particular sample size. The broad strategy for selection of the afore-said 17 healthcare units revolved around the following:

1. Identification of the main public and private healthcare units operating in Sagar Island;
2. Classification of the public and private healthcare units to be surveyed on the basis of services they are rendering to the coastal community at large;

3. Geographical distribution of the surveyed units;

4. Selection of units is to be done keeping in mind the influx of patients/ beneficiaries per day on an average basis to the varied healthcare units.

After due diligence through a series of small focus group discussions with the community, 17 units of varied types supporting the healthcare system in Sagar Island were identified for the study. The details of the said 17 units are given in Table D (Annexure). As derived from the focus group discussions from the public sector healthcare facilities, the block rural hospital and the primary healthcare centres were considered for the study. In addition to it, from the total population of the private units dealing with healthcare services and facilities, the number of units that were considered are noted in Table 1 below.

Table 1: Private Healthcare Units Vis- a-Vis the Surveyed Healthcare Units

\begin{tabular}{|lcc|}
\hline Type of the Healthcare Facility & Total Population & Surveyed Units \\
\hline Nursing home & 1 & 1 \\
Medical store/druggist \&chemist shops & 30 & 6 \\
Physiotherapy clinic & 1 & 1 \\
Pathological diagnostic centre & 10 & 3 \\
ECG-cum-medical imaging unit & 2 & 2 \\
\hline
\end{tabular}

Journal of Rural Development, Vol. 36, No. 3, July-September : 2017 
In addition to the above, Table 2 testifies the span of coverage of the Gram Panchayats vis-à-vis the healthcare units that were selected for the study in Sagar Island. The questionnaire that was put forward to the respondents/ interviewees of the identified healthcare units in the survey is a blend of both objective and subjective elements. Apart from the written questionnaire, impromptu short duration discussions, duly video-graphed with the respondents/interviewees, were also conducted in a bid to capture every bit of material information.

Table 2: Geographical Distribution of the Surveyed Healthcare Units

\begin{tabular}{|c|c|c|c|c|c|c|c|c|}
\hline 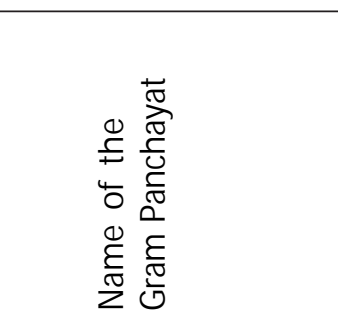 & 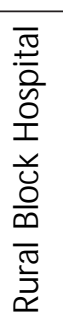 & 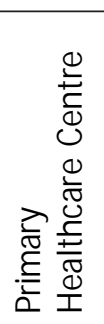 & 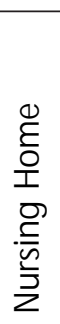 & 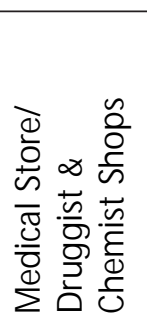 & 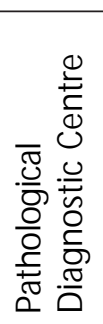 & 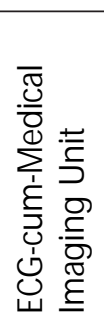 & 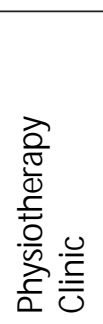 & 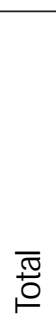 \\
\hline Rudranagar & 1 & - & 1 & 2 & 2 & 1 & 1 & 8 \\
\hline Gangasagar & - & 1 & - & - & - & - & - & 1 \\
\hline Dablat & - & - & - & 2 & 1 & - & - & 3 \\
\hline Muriganga I & - & 1 & - & - & - & - & - & 1 \\
\hline Muriganga II & - & - & - & 1 & - & - & - & 1 \\
\hline Dasparasumatinagar I & - & 1 & - & - & - & - & - & 1 \\
\hline Dasparasumatinagar II & - & - & - & - & - & 1 & - & 1 \\
\hline Ramkarchar & - & - & - & 1 & - & - & - & 1 \\
\hline Total & 1 & 3 & 1 & 6 & 3 & 2 & 1 & 17 \\
\hline
\end{tabular}

\section{Results and Discussion}

Respondents of the study belong to a varied range, as it includes physicians, pharmacists, radiographers, pathologists, proprietors of medical stores/nursing home and rural health assistants. The data collected through the key informant interviews were duly processed and the major findings are summarised below:

1. Summarised profile of the 17 surveyed units vis-à-vis its employability and patients/consumers/customers catered per day mentioned in Table 3.

2. Out of the 17 units, 16 are connected to the grid electricity. One primary health centre located in Muriganga I Gram Panchayat is yet to be connected to the grid electricity but the same has already applied for connection.

3. All the 16 units connected now with the grid electricity, earlier had to depend 
on either of the following or a combination of the following for sustenance of their activities.

- Power supplied through DG sets for 4 hours from WBSEDCL's end

- Some of the studied units also procured services of privatelyowned and managed DG sets.

- Some units were also connected with solar installations but the maintenance of the same was an issue to them.

- Illumination through kerosene lamps was also done at the premises of the surveyed units.

4. The extent of enhancement of healthcare services and facilities due to induction of grid electricity by the surveyed units was studied from two accounts: a) application of financial resources and b) benefits that are now being permeated to the coastal community in consonance with the trickledown theory with enhanced capacity facilitation coupled with service level augmentation.

5. The study found that grid electricity has contributed to a large extent in the spurt in CAPEX (Capital Expenditure) of the surveyed units as the same have bought either new light, fan, computer, fridge and air condition machines collectively termed here as non-medical appliances or have procured/installed electric fed or dependent medical appliances in order to have facility augmentation at their respective units. It is worthwhile to note that before grid electricity only two surveyed units have three computers in all, but after grid electricity six surveyed units are now having 14 computers.

Table 3: Number of Employees Hired and Beneficiaries/ Patients/Consumers/ Customers Catered by the Surveyed Healthcare Units

\begin{tabular}{|c|c|c|c|}
\hline $\begin{array}{c}\text { Type of Organisation/ } \\
\text { Firm }\end{array}$ & $\begin{array}{l}\text { mber of } \\
\text { ations/ Firms } \\
\text { erviewed }\end{array}$ & $\begin{array}{c}\text { Number of Employees } \\
\text { Employed (including } \\
\text { the owner as the case } \\
\text { may be) }\end{array}$ & $\begin{array}{c}\text { Number of } \\
\text { Beneficiaries/ Patients/ } \\
\text { Consumers/Customers } \\
\text { Catered Per Day } \\
\text { (Estimated) }\end{array}$ \\
\hline Rural block hospital & 1 & 298 & 371 \\
\hline Primary healthcare centre & 3 & 13 & 170 \\
\hline Nursing home & 1 & 17 & 33 \\
\hline Medical store/ & & & \\
\hline Druggist $\&$ chemist shops & 6 & 16 & 430 \\
\hline Pathological diagnostic centre & 3 & 8 & 64 \\
\hline ECG-cum-medical imaging unit & 2 & 5 & 85 \\
\hline Physiotherapy clinic & 1 & 1 & 10 \\
\hline Total & 17 & 358 & 1163 \\
\hline
\end{tabular}

Journal of Rural Development, Vol. 36, No. 3, July-September : 2017 
The monthly REVEX (Revenue Expenditure) of the surveyed units for meeting energy requirements are also showing signs of upswing despite cost cutting to a large extent on DG set account except one ECGcum-medical imaging unit which has admitted to have fault prone metre - resulting in inadvertent errors related to computation of units consumed. The primary reasons for the upswing in both CAPEX \& REVEX are:

- Installation of new electric-fed or operated appliances

- Enhancement of duration of daily service period by most of the public and private healthcare units that were studied.
The undernoted charts testify the abovementioned arguments. Analysis of Figure 1 along with Table $B$ in annexure portrays the usage of electric-fed appliances before and after the introduction of grid electricity with respect to the studied units. Percentage hike on the usage of electric powered appliances that were put on use after the said surveyed units were connected to grid electricity are noted below:

Non-medical appliances: 39.86 per cent

Medical appliances: 233 per cent

Non-medical and medical appliances: 47.52 per cent

Figure 1: Usage of Electric Powered Appliances Before and After Grid Electricity

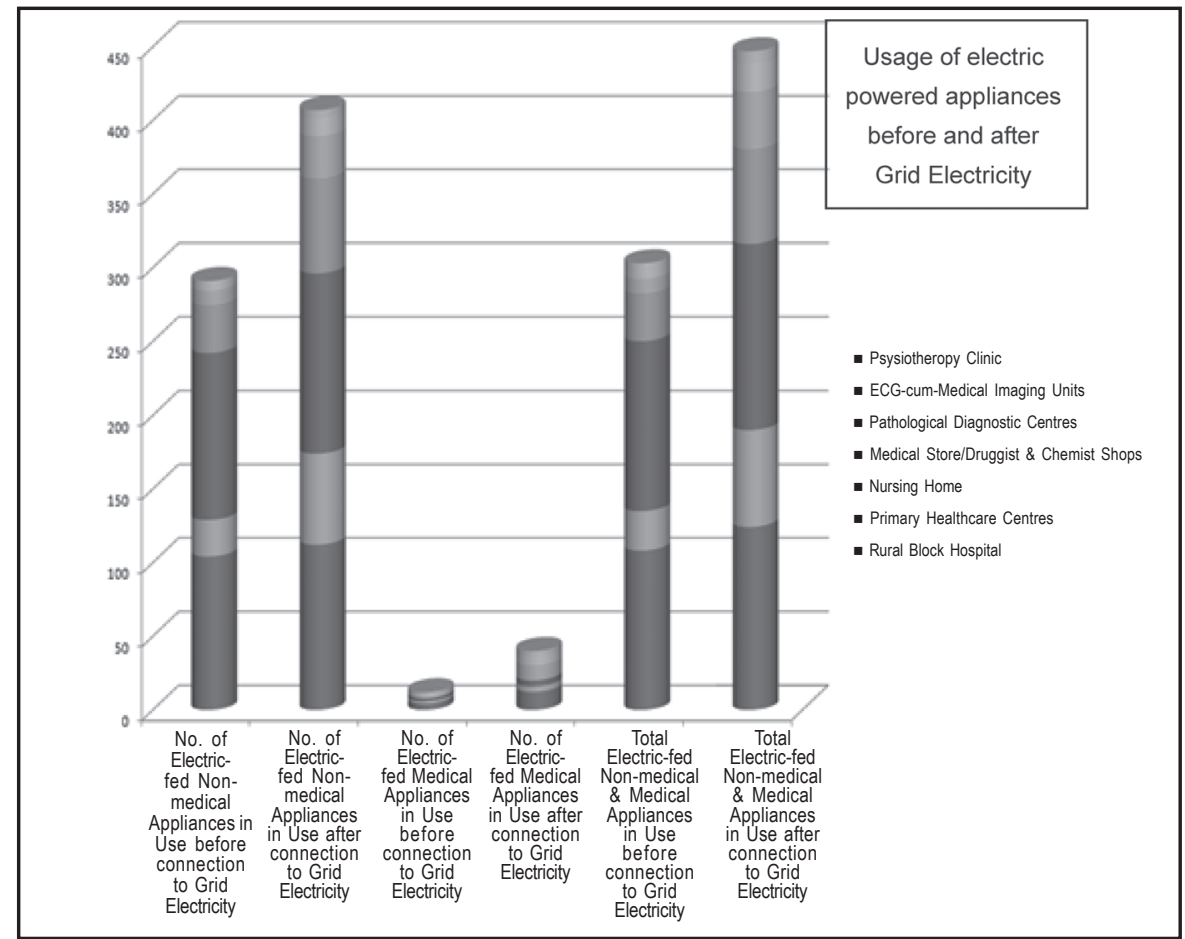

Journal of Rural Development, Vol. 36, No. 3, July-September : 2017 
Figures 2 and 3 should also be read with Table $\mathrm{C}$ in annexure which is a testimony of the fact that the capital expenditure was incurred as the healthcare units released the scope of enhancement of their activity in a bid to make healthcare facilities and services more accessible to the coastal community. The factor for potential revenue yield apart from the social cause by the privately-owned healthcare units should not be discounted as many of them concurred to the fact that their customer base has increased in tandem with capacity enhancement and extension of serviceability duration. Similarly, the spikes witnessed in Figure 3 corroborate the aforementioned argument.

Figure 2: Capital Expenditure Incurred Owing to Grid Electrification (Estimated)

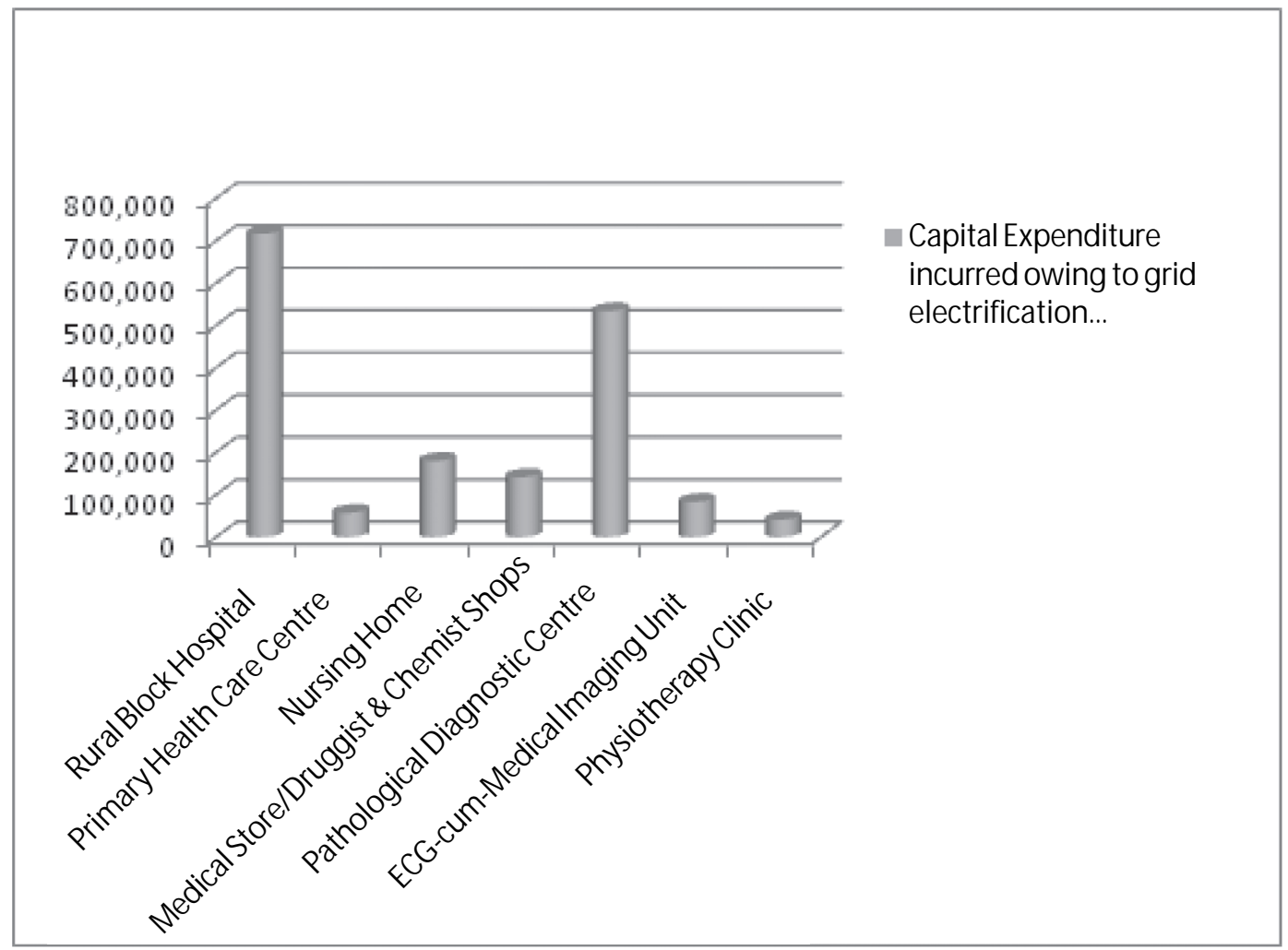


Figure 3: Growth in Revenue Expenditure with Respect to Energy User Charges

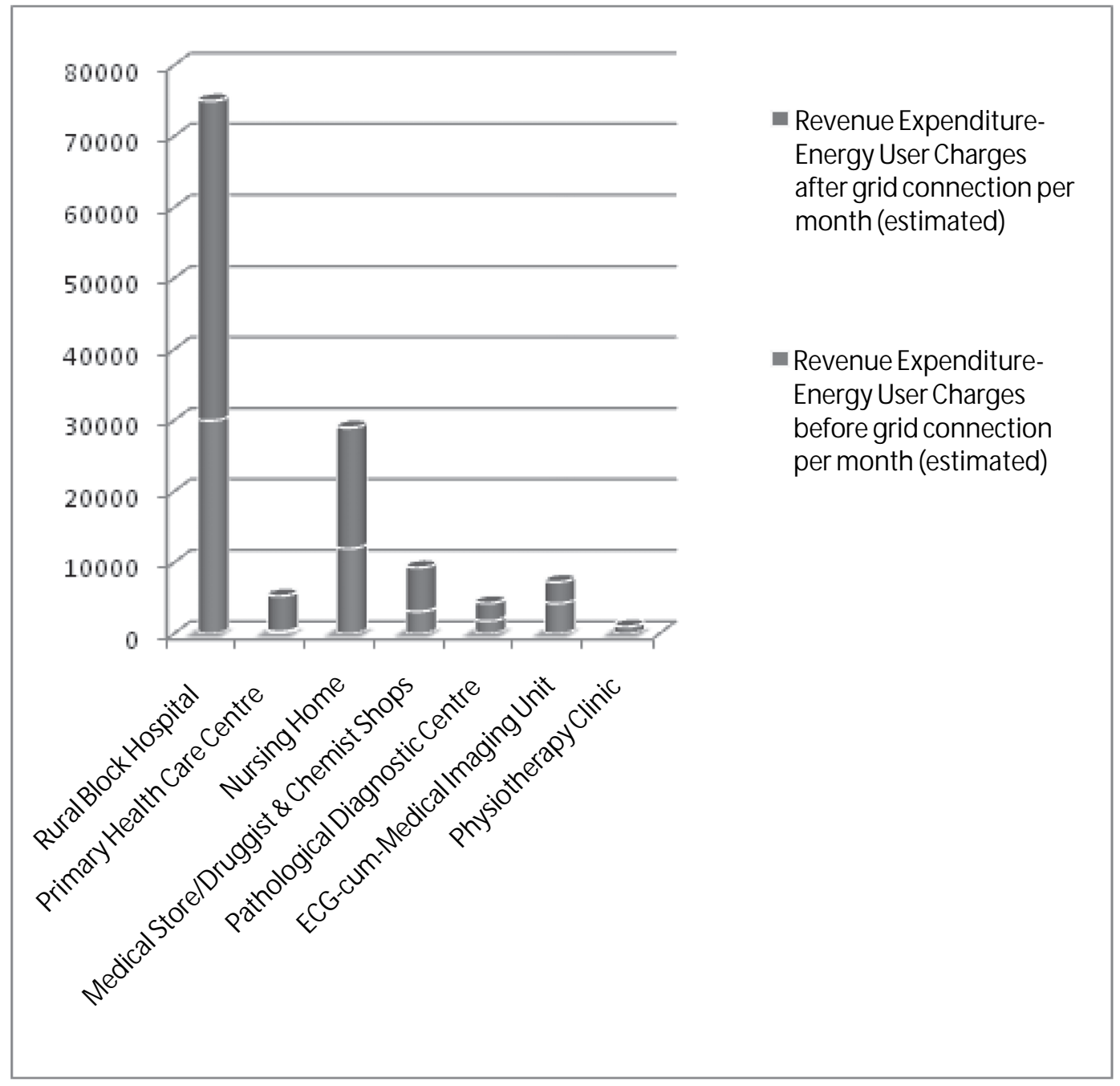

6. As a corollary to the above point, the surveyed units that are connected to the grid electricity have concurred, both in qualitative and quantitative terms, their service and facility level to its primary stakeholders have increased manifold. Significant points on this account have been elaborated in Table 4.
7. All the 16 units connected with the grid electricity are satisfied with the services provided by WBSEDCL. Data as analysed also show that four out of sixteen units connected to the grid electricity had ever lodged complaints against the service provider in the last couple of years but all the lodged 
complaints were resolved to the satisfaction of the consumers, i.e., the surveyed units.

8. The key informants have also shared their experience on frequency of power disruption. Majority of them stated that they do experience 15-30 minutes load shedding daily. Power outages sometimes do happen for 2-3 hours due to pending electrification work or for maintenance of transformer burnouts and cable faults. In addition to it, preventive major power cuts do happen for more than 10 hours in case of cyclonic storm surges.

Table 4: Situation Before and After Connection with Grid Electricity in the Surveyed Healthcare Units in Sagar Island

\begin{tabular}{|c|c|c|}
\hline $\begin{array}{l}\text { Type of } \\
\text { Organisation/ Firm }\end{array}$ & $\begin{array}{l}\text { Situation Before Connection with } \\
\text { Grid Electricity }\end{array}$ & $\begin{array}{l}\text { Situation After Connection with Grid } \\
\text { Electricity }\end{array}$ \\
\hline $\begin{array}{l}\text { Rural block } \\
\text { hospital }\end{array}$ & $\begin{array}{l}\text { The rural block hospital used the } \\
\text { power supplied through DG sets } \\
\text { of WBSEDCL and through } \\
\text { privately-owned DG sets. A } \\
\text { number of medical and non- } \\
\text { medical appliances were already } \\
\text { put to use before theintroduction } \\
\text { of grid electricity. Major electric- } \\
\text { fed medical appliances used } \\
\text { include X-ray, phototherapy } \\
\text { machine ( used for reducing high } \\
\text { bilirubin levels that cause jaundice } \\
\text { in a newborn) and incubator. }\end{array}$ & $\begin{array}{l}\text { Post-grid electricity connection- the } \\
\text { rural block hospital has undergone a } \\
\text { major facility upgradation. It has set } \\
\text { up a blood bank-cum-transfusion unit } \\
\text { and pathological laboratory. The } \\
\text { pathological laboratory is equipped } \\
\text { with analyser, microscope and other } \\
\text { devices. Several pathological tests are } \\
\text { now being done which include blood } \\
\text { tests for thyroid, sugar, malaria, HIV } \\
\text { and other sexually transmitted } \\
\text { diseases and sputum, urine, etc. Drug } \\
\text { administration with enhanced } \\
\text { refrigeration capacity due to } 24 x 7 \\
\text { grid power also gets a fillip with the } \\
\text { introduction of the following (in } \\
\text { qualitative and quantitative manner): } \\
\text { Injection AVS - anti snake venom } \\
\text { Injection Syntocinon - used for } \\
\text { induction of labour process } \\
\text { medications, etc. Injection } \\
\text { Pentavalent- combination of five } \\
\text { vaccines in one, i.e., diphtheria, } \\
\text { tetanus, whooping cough, hepatitis-B } \\
\text { and haemophilus influenza type b. } \\
\text { Apart from the above BCG vaccine } \\
\text { (used for prevention of tuberculosis, } \\
\text { other vaccines, e.g., to prevent spread } \\
\text { of polio and measles are also being }\end{array}$ \\
\hline
\end{tabular}

Journal of Rural Development, Vol. 36, No. 3, July-September : 2017 


\begin{tabular}{|c|c|c|}
\hline $\begin{array}{l}\text { Type of } \\
\text { Organisation/ Firm }\end{array}$ & $\begin{array}{l}\text { Situation Before Connection with } \\
\text { Grid Electricity }\end{array}$ & $\begin{array}{l}\text { Situation After Connection with Grid } \\
\text { Electricity }\end{array}$ \\
\hline & & $\begin{array}{l}\text { administered from the hospital. } \\
\text { Recently installed major electric-fed } \\
\text { medical appliances include: } \\
\text { - Suction machine- used "to remove } \\
\text { substances, such as mucus or serum, } \\
\text { from a body cavity". } \\
\text { - Pulse oximeter - indirectly monitors } \\
\text { the oxygen saturation of a patient's } \\
\text { blood and changes in blood volume } \\
\text { in the skin, producing a } \\
\text { photoplethysmogram. It aids in } \\
\text { monitoring heart rate and cardiac } \\
\text { cycle, respiration, depth of anesthesia, } \\
\text { hypo- and hypervolemia. } \\
\text { - Baby warmer - used to save the } \\
\text { lives of premature and low-birth } \\
\text { weight babies suffering from } \\
\text { hypothermia. } \\
\text { - Electric stream steriliser \& vertical } \\
\text { steriliser- used for sterilisation of the } \\
\text { consumables in the labour room. } \\
\text { Both the occurrences of major and } \\
\text { minor operations have increased in } \\
\text { the hospital. Cesarean sections are } \\
\text { now being done with ease. In } \\
\text { addition to this, electric pump-fed } \\
\text { water supply facility has also been } \\
\text { improved. }\end{array}$ \\
\hline $\begin{array}{l}\text { Primary healthcare } \\
\text { centre }\end{array}$ & $\begin{array}{l}\text { Out of three surveyed units, } \\
\text { primary health centre at } \\
\text { Gangasagar Gram Panchayat was } \\
\text { connected with DG set backed } \\
\text { power source and while that at } \\
\text { Dasparasumatinagar I Gram } \\
\text { Panchayat had to depend on solar } \\
\text { power but that too had become } \\
\text { dysfunctional about seven years } \\
\text { ago. Boiler and syringe destroyer } \\
\text { were being used through DG } \\
\text { sets backed power supply in } \\
\text { Gangasagar Gram Panchayat while } \\
\text { in Dasparasumatinagar I Gram }\end{array}$ & $\begin{array}{l}\text { At present two out of three primary } \\
\text { health centres are being connected } \\
\text { to the grid electricity. The two } \\
\text { connected primary health centres } \\
\text { located at Gangasagar and } \\
\text { Dasparasumatinagar I Gram } \\
\text { Panchayats, respectively, are now } \\
\text { providing services with ease as have } \\
\text { been expressed by the staff of the } \\
\text { same.Primary health centres situated } \\
\text { in Gangasagar are now using boiler } \\
\text { and syringe destroyer with the aid of } \\
\text { grid electricity. }\end{array}$ \\
\hline
\end{tabular}

Journal of Rural Development, Vol. 36, No. 3, July-September : 2017 


\begin{tabular}{|c|c|c|}
\hline $\begin{array}{l}\text { Type of } \\
\text { Organisation/ Firm }\end{array}$ & $\begin{array}{l}\text { Situation Before Connection with } \\
\text { Grid Electricity }\end{array}$ & $\begin{array}{l}\text { Situation After Connection with Grid } \\
\text { Electricity }\end{array}$ \\
\hline & $\begin{array}{l}\text { Panchayat sterilisation of medical } \\
\text { instruments were done through } \\
\text { kerosene (consuming } 4 \text { litres of } \\
\text { kerosene per month) fed boiling } \\
\text { systems. Primary health centre } \\
\text { located in Muriganga I Gram } \\
\text { Panchayat was not connected } \\
\text { with either DG sets or solar } \\
\text { systems. Only in case of some } \\
\text { emergencies some temporary DG } \\
\text { sets backed lighting arrangements } \\
\text { were done. }\end{array}$ & $\begin{array}{l}\text { Primary health centres located in } \\
\text { Dasparasumatinagar I have undergone } \\
\text { a major facility augmentation through } \\
\text { installation of both electric-fed } \\
\text { medical and non-medical appliances. } \\
\text { Electric-fed medical appliances } \\
\text { operated now include microscope for } \\
\text { investigation of blood samples, } \\
\text { especially for detection of malaria } \\
\text { and a steriliser for disinfection of } \\
\text { invasive medical instruments. } \\
\text { Primary health centre located in } \\
\text { Muriganga I Gram Panchayat has also } \\
\text { applied for grid electricity and soon } \\
\text { the same will be connected with the } \\
\text { grid. }\end{array}$ \\
\hline Nursing home & $\begin{array}{l}\text { The nursing home located at } \\
\text { Rudranagar Gram Panchayat used } \\
\text { the power supplied through DG } \\
\text { sets of WBSEDCL and through } \\
\text { privately-owned DG sets. A } \\
\text { number of medical and non- } \\
\text { medical appliances were put on } \\
\text { use before induction of grid } \\
\text { electricity. Electric-fed medical } \\
\text { appliances used were ECG and } \\
\text { USG machines. }\end{array}$ & $\begin{array}{l}\text { The nursing home has concurred that } \\
\text { due to } 24 \times 7 \text { grid electricity, some } \\
\text { major facility upgradations have been } \\
\text { undertaken by the same. Electric-fed } \\
\text { medical appliances procured and used } \\
\text { mainly for surgical purposes include } \\
\text { (a) diatherm for blood coagulation } \\
\text { and blood vessel cauterisation during } \\
\text { operation and (b) cardiac monitor for } \\
\text { cardiovascular system measurement } \\
\text { and treatment. } \\
\text { Transfusion of blood and blood } \\
\text { fractions are also now being done at } \\
\text { the unit. Drug administration } \\
\text { enhanced with the introduction of } \\
\text { Termin, Scolin, Myopyrolate, Adrenaline } \\
\text { and Propofol- used for anesthesia. } \\
\text { Major surgical operations increased } \\
\text { from } 10 \text { to } 20 \text {, in case of minor } \\
\text { operations from } 30 \\
\text { cases.Capacities for aiding pathological } 50 \\
\text { tests have also increased as more } \\
\text { specimens can be collected and } \\
\text { preserved for investigation. }\end{array}$ \\
\hline
\end{tabular}




$\begin{array}{lll}\text { Type of } & \text { Situation Before Connection with } & \text { Situation After Connection with Grid } \\ \text { Organisation/Firm } & \text { Grid Electricity } & \text { Electricity }\end{array}$

\begin{tabular}{|c|c|c|}
\hline $\begin{array}{l}\text { Medical store/ } \\
\text { druggist \& chemist } \\
\text { shops }\end{array}$ & $\begin{array}{l}\text { Medical shops/drug stores that } \\
\text { were surveyed had narrated in } \\
\text { unambiguous terms that prior to } \\
\text { grid electricity they used to } \\
\text { preserve the bare minimal } \\
\text { quantum of drugs in a format } \\
\text { that may not be subscribed to } \\
\text { be proper. Some of the } \\
\text { interviewees recounted that due } \\
\text { to lack of electric-fed } \\
\text { refrigeration units, drugs were } \\
\text { kept in ice bags or ice boxes } \\
\text { meant for ferrying fish catch to } \\
\text { the mainland. However, most of } \\
\text { the drugs which are required for } \\
\text { daily usages or in emergency } \\
\text { situations in the island are } \\
\text { generally being procured from } \\
\text { the two main junction points of } \\
\text { mainland, i.e., Kakdwip and } \\
\text { Diamond Harbour either daily or } \\
\text { on real time basis as the case } \\
\text { may be. The source energy for } \\
\text { operating the minimal electrical } \\
\text { devices at the druggist stores } \\
\text { are either DG sets or solar power. }\end{array}$ & $\begin{array}{l}\text { The situation has changed } \\
\text { dramatically with the introduction of } \\
\text { grid electricity in all the surveyed } \\
\text { units. It came out from the study that } \\
\text { all the surveyed medical shops/drug } \\
\text { stores kept open their establishments } \\
\text { even during late evening hours, which } \\
\text { were quite unbecoming about } 2-3 \\
\text { years back. The benefit accrued is in } \\
\text { both ways. Patient parties get the } \\
\text { drugs on real time basis while } \\
\text { volume of business on drugs and } \\
\text { allied accessories get a new stimulus } \\
\text { for growth and development. All of } \\
\text { the surveyed units have procured } \\
\text { refrigeration units (fridge) and are } \\
\text { now inventorising drugs (some are } \\
\text { not only essential but also life-saving } \\
\text { in nature) which require refrigeration. } \\
\text { Some of the drugs noted below are } \\
\text { worth mentioning: } \\
\text { - Humulin 70/30, Actrapid and Mixtard } \\
\text { - varied forms of insulin are being } \\
\text { used for treatment of diabetic } \\
\text { patients. } \\
\text { - Depo Medrol - an anti-inflammatory } \\
\text { glucocorticoid for intramuscular, intra- } \\
\text { articular, soft tissue or intralesional } \\
\text { injection relieves patients swelling, } \\
\text { itching, and redness } \\
\text { inflammats affory } \\
\text { insuripur- used to prevent or treat } \\
\text { infection by the virus that causes } \\
\text { rabies } \\
\text { osteoarthritis, active chronic hepatitis, } \\
\text { tuberculosis, severe lepra reaction, }\end{array}$ \\
\hline
\end{tabular}




\begin{tabular}{|c|c|c|}
\hline $\begin{array}{l}\text { Type of } \\
\text { Organisation/ Firm }\end{array}$ & $\begin{array}{l}\text { Situation Before Connection with } \\
\text { Grid Electricity }\end{array}$ & $\begin{array}{l}\text { Situation After Connection with Grid } \\
\text { Electricity }\end{array}$ \\
\hline & & $\begin{array}{l}\text { certain forms of bacterial meningitis, } \\
\text { pneumocystis, etc. } \\
\text { Depo-Provera- a progesterone } \\
\text { injection which is used in } \\
\text { contraception. } \\
\text { Dulcolax Laxative Suppositories - } \\
\text { relieves the ailing patients from } \\
\text { constipation. }\end{array}$ \\
\hline $\begin{array}{l}\text { Pathological } \\
\text { diagnostic centre } \\
\text { ECG-cum-medical } \\
\text { imaging unit }\end{array}$ & $\begin{array}{l}\text { It appears from the narratives of } \\
\text { the respondents that one of } \\
\text { them has recently started the } \\
\text { enterprise. The other two } \\
\text { establishments, which were } \\
\text { functioning before grid } \\
\text { electricity, generally, rely on } \\
\text { manual testing methods on the } \\
\text { collected samples and that too } \\
\text { are few in nature. In addition to } \\
\text { that, pathological labs used to } \\
\text { send specimens to Kolkata and } \\
\text { elsewhere for testing; even } \\
\text { though the technicians in Sagar } \\
\text { Island do have the requisite } \\
\text { knowledge base to perform the } \\
\text { same.Two out of three units } \\
\text { were using DG set backed } \\
\text { power supply before the advent } \\
\text { of grid electricity. }\end{array}$ & $\begin{array}{l}\text { In the post-grid electrification phase } \\
\text { all the surveyed units have procured } \\
\text { number of electric-fed medical and } \\
\text { non-medical appliances. Major medical } \\
\text { appliances bought noted in bracketed } \\
\text { figures and its usages have been } \\
\text { stated below: } \\
\text { Microscope (2) -aids in investigation } \\
\text { of collected specimens and } \\
\text { identification of possible presence of } \\
\text { microorganisms using artificial light } \\
\text { source. } \\
\text { Incubator (2) -assists in sample } \\
\text { storage system for culture of micro- } \\
\text { organisms in urine and blood in a } \\
\text { controlled atmosphere } \\
\text { Centrifuge (3)- used for assessing of } \\
\text { hematocrit, serum analysis and } \\
\text { plasma separation } \\
\text { Semi auto-analyser (1) - assists in } \\
\text { liver and kidney function } \\
\text { determination, lipids, glucose and ion } \\
\text { test, etc. } \\
\text { Colorimetre (2)-used to assess levels } \\
\text { of different biochemical parameters. } \\
\text { Consequent to the facility, upgradation } \\
\text { of the surveyed units have resulted } \\
\text { in conducting several pathological } \\
\text { tests in Sagar Island, e.g., Sodium } \\
\text { Potassium, Liver Function, Lipid Profile, } \\
\text { Blood Sugar, Urea, Creatinine } \\
\text { Phosphokinase and Creatinine } \\
\text { Phosphokinase Cardiac Muscle } \\
\text { Isoenzyme. }\end{array}$ \\
\hline
\end{tabular}




\begin{tabular}{|c|c|}
\hline $\begin{array}{l}\text { Type of } \\
\text { Organisation/ Firm }\end{array}$ & $\begin{array}{l}\text { Situation Before Connection witl } \\
\text { Grid Electricity }\end{array}$ \\
\hline & $\begin{array}{l}\text { Before grid electricity, both the } \\
\text { surveyed units have ECG and X- } \\
\text { ray machines. In earlier } \\
\text { occasions, power supplied } \\
\text { through DG sets were prone to } \\
\text { voltage fluctuations and this had } \\
\text { led to generate not so accurate } \\
\text { results in case of X-ray or ECG } \\
\text { of the patients. }\end{array}$ \\
\hline
\end{tabular}

Physiotherapy Prior to grid electricity the clinic centre was not in existence.
The respondents of the surveyed units noted that both the quality and duration of rendering services to their customers have improved. Now the grid-fed ECG and medical imaging ( $X$ ray) devices are powering the outputs with higher degree of accuracy and precision. One of the surveyed units has recently procured a Nebulizer and Tooth Scaling machine in a bid to expand its scope of activities.

The newly established physiotherapy clinic which becomes functional after induction of grid power in Sagar Island has deployed several electric-fed equipment, e.g., Ultrasound, Short Wave Diathermy and Interferential Therapy (IFT) machines for relieving patients from inflammation, muscular spasms, strains, sprains, etc.

\section{Future Scope of the Study}

The scope of the study can be enhanced by taking into consideration the volume of business of medical supplies that are being done now in comparison to two to three years back by the distributors and the same should be shown in reconciliation with the opinions from the consumers'/customers' end.

\section{Conclusion}

The development narrative sets through grid electricity is quite clear, i.e., a wellexecuted project having the potential of transforming lives not only succeeds at the implementation level but also accelerates the momentum to unplug the entrepreneurial spirit of the community. The benefit accrued in the healthcare sector due to grid electricity is a layered one having multiplier impact. Indeed, due to grid electricity service facility augmentations of the healthcare units have taken place in Sagar Island, both in quantitative and qualitative terms, and this has benefited the residents of the island who were generally transshipped in earlier occasions to the mainland even for treatment of minor ailments. 


\section{References}

1. Autoclave;web:http://www.pharmainfo.net/book/pharmaceutical-machines/autoclave

2. Directorate of Census Operations, West Bengal; District Census Handbook South Twenty Four Parganas Village and Town Wise Primary Census Abstract,(PCA);web:http:// www.censusindia.gov.in/2011census/dchb/1917_PART_B_DCHB_SOUTH\%20TWENTY\% 20FOUR\% 20PARGANAS.pdf.

3. Farlex; The Free Dictionary's Medical Dictionary; Incubator; web: http://medical-dictionary. thefreedictionary.com/incubator.

4. Memorandum of Understanding for Pilot Investment in Distribution of Grid Electricity in Sagar Island between the West Bengal State Project Management Unit and West Bengal State Electricity Distribution Company Limited; web: http://www.iczmpwb.org/main/pdf/ pea/MOU_WBSEDCL.pdf.

5. Pentavalent vaccine; web: https://en.wikipedia.org/wiki/Pentavalent_vaccine.

6. Social Development Knowledge Platform; web: https://sustainabledevelopment.un.org/ ?menu=1300.

7. Suction Machines; web: https://www.specialty-medical.com/suction_machines.html.

8. The World Bank (2010), "Project Appraisal Document on A Proposed Credit in the Amount of SDR 146.9 Million (US\$221.96 Million Equivalent) to the Republic of India for an Integrated Coastal Zone Management Project," May 14, 2010, web: http:// www.iczmpwb.org/main/pdf/pd/Final_PAD.pdf.

9. $\quad$--------- (2014), "India Integrated Coastal Zone Management Project Implementation Support and Review Mission: Aide Memoire," September 15 -October 22, 2014;web: http://www.iczmpwb.org/main/pdf/pd/ICZMP\%20Aide\%20Memoire\%20-Final.pdf.

10. Web MD; Phototherapy for Jaundice in Newborns - Topic Overview;web:http:// www.webmd.com/parenting/baby/tc/phototherapy-for-jaundice-in-newborns-topicoverview.

11. West Bengal State Electricity Distribution Corporation Limited, "100 Per Cent Household Electrification of Sagar Island: Detailed Project Report," web:http://www.iczmpwb.org/ main/pdf/pea/detailed_project_report_wbsedcl.pdf.

12. Wikipedia; Quota sampling; web: https://en.wikipedia.org/wiki/Quota_Sampling.

Journal of Rural Development, Vol. 36, No. 3, July-September : 2017 
ANNEXURE

Table A: State Project Management Unit (SPMU)/ Pilot Investment Executing Agencies (PIEAs) Allocation of Project Components

Project Component Description

Project Component Allocation among the Respective PIEAs and SPMU

ICZM Plan Preparation

Capacity Building for officials of State government/ academicians/researchers, members of civil society organisations and selected representatives of coastal communities

CBO Coordinated Livelihood Improvement \& Market Access in Sagar Block

Development of Eco-tourism in Sagar Island

100 Per Cent Household Electrification in Sagar Island

Development of Coastal Bio-shield in 6 Coastal Blocks of East Midnapore District

Strengthening of the Marine Aquarium and Regional Centre in Digha

Renovation of Sanitary Sewerage Scheme in Digha

Development of Drainage System and Phytoremediation in Digha

Beach Cleaning \& Sanitation, Beach Beautification \& Illumination, Livelihood Generation in Digha

Solid Waste Management in Digha

Post-harvest Handling and Fish Auction Centre at Mohanain Digha

State Project Management Unit

State Project Management Unit/ West Bengal State Rural Livelihood Mission

Sunderban Infrastructure Development Corporation Limited

West Bengal State Electricity Distribution Limited

Forest Directorate

Zoological Survey of India

Public Health Engineering Directorate

Digha Sankarpur Development Authority

West Bengal Fisheries Corporation Limited 
Table A (Contd.....)

\begin{tabular}{|ll|}
\hline Project Component Description & $\begin{array}{l}\text { Project Component Allocation } \\
\text { among the Respective PIEAsand } \\
\text { SPMU }\end{array}$ \\
\hline $\begin{array}{l}\text { Capacity Building for Remote Sensing \&GIS Laboratory \& } \\
\text { Climate Change Studies }\end{array}$ & $\begin{array}{l}\text { Institute ofEnvironmental Studies } \\
\& \text { Wetland Management }\end{array}$ \\
$\begin{array}{l}\text { Construction of Multi-Purpose Cyclone Sheltersin 5Coastal } \\
\text { Blocks of South 24 Parganas }\end{array}$ & $\begin{array}{l}\text { Department of Disaster } \\
\text { Management }\end{array}$ \\
$\begin{array}{l}\text { Capacity Building for Climate ChangeStudies-Cataloguing } \\
\text { and Describing the Microbial Diversity ofSundarban }\end{array}$ & $\begin{array}{l}\text { Department of Bio-chemistry, } \\
\text { Calcutta University }\end{array}$ \\
\hline
\end{tabular}

Table B: Status of Electric Fed Appliances Before and After Grid Electricity in Surveyed Healthcare Units

\begin{tabular}{|c|c|c|c|c|c|c|}
\hline $\begin{array}{l}\text { Type of Organisation/ } \\
\text { Firm }\end{array}$ & $\begin{array}{l}\text { No. of } \\
\text { Electric- } \\
\text { fed Non- } \\
\text { Medical } \\
\text { Appliances } \\
\text { in Use } \\
\text { Before } \\
\text { Connection } \\
\text { to Grid } \\
\text { Electricity } \\
\text { (A) }\end{array}$ & $\begin{array}{l}\text { No. of } \\
\text { Electric- } \\
\text { fed Non- } \\
\text { medical } \\
\text { Appliances } \\
\text { in Use } \\
\text { after } \\
\text { Connection } \\
\text { to Grid } \\
\text { Electricity } \\
\text { (B) }\end{array}$ & $\begin{array}{l}\text { No. of } \\
\text { Electric- } \\
\text { fed } \\
\text { Medical } \\
\text { Appliances } \\
\text { in Use } \\
\text { Before } \\
\text { Connection } \\
\text { to Grid } \\
\text { Electricity } \\
\text { (C) }\end{array}$ & $\begin{array}{l}\text { No. of } \\
\text { Electric- } \\
\text { fed } \\
\text { Medical } \\
\text { Appliances } \\
\text { in Use } \\
\text { After } \\
\text { Connection } \\
\text { to Grid } \\
\text { Electricity } \\
\text { (D) }\end{array}$ & $\begin{array}{c}\text { Total } \\
\text { Electric- } \\
\text { fed Non- } \\
\text { medical \& } \\
\text { Medical } \\
\text { Appliances } \\
\text { in Use } \\
\text { Before } \\
\text { Connection } \\
\text { to Grid } \\
\text { Electricity } \\
\text { (A+C) }\end{array}$ & $\begin{array}{c}\text { Total } \\
\text { Electric- } \\
\text { fed Non- } \\
\text { medical \& } \\
\text { Medical } \\
\text { Appliances } \\
\text { in Use } \\
\text { After } \\
\text { Connection } \\
\text { to Grid } \\
\text { Electricity } \\
\text { (B+D) }\end{array}$ \\
\hline Rural Block Hospital & 104 & 112 & 4 & 12 & 108 & 124 \\
\hline $\begin{array}{l}\text { Primary Healthcare } \\
\text { Centres }\end{array}$ & 25 & 62 & 2 & 4 & 27 & 66 \\
\hline Nursing Home & 113 & 122 & 2 & 4 & 115 & 126 \\
\hline $\begin{array}{l}\text { Medical Store/ Druggist } \\
\& \text { Chemist Shops }\end{array}$ & 32 & 64 & - & - & 32 & 64 \\
\hline $\begin{array}{l}\text { Pathological } \\
\text { Diagnostic Centres }\end{array}$ & 10 & 29 & - & 10 & 10 & 39 \\
\hline $\begin{array}{l}\text { ECG-cum-M edical } \\
\text { Imaging Units }\end{array}$ & 7 & 13 & 4 & 7 & 11 & 20 \\
\hline
\end{tabular}

Journal of Rural Development, Vol. 36, No. 3, July-September : 2017 
Table B (Contd.....)

\begin{tabular}{|c|c|c|c|c|c|c|}
\hline $\begin{array}{l}\text { Type of Organisation/ } \\
\text { Firm }\end{array}$ & $\begin{array}{l}\text { No. of } \\
\text { Electric- } \\
\text { fed Non- } \\
\text { Medical } \\
\text { Appliances } \\
\text { in Use } \\
\text { Before } \\
\text { Connection } \\
\text { to Grid } \\
\text { Electricity } \\
\text { (A) }\end{array}$ & $\begin{array}{l}\text { No. of } \\
\text { Electric- } \\
\text { fed Non- } \\
\text { medical } \\
\text { Appliances } \\
\text { in Use } \\
\text { after } \\
\text { Connection } \\
\text { to Grid } \\
\text { Electricity } \\
\text { (B) }\end{array}$ & $\begin{array}{l}\text { No. of } \\
\text { Electric- } \\
\text { fed } \\
\text { Medical } \\
\text { Appliances } \\
\text { in Use } \\
\text { Before } \\
\text { Connection } \\
\text { to Grid } \\
\text { Electricity } \\
\text { (C) }\end{array}$ & $\begin{array}{l}\text { No. of } \\
\text { Electric- } \\
\text { fed } \\
\text { Medical } \\
\text { Appliances } \\
\text { in Use } \\
\text { After } \\
\text { Connection } \\
\text { to Grid } \\
\text { Electricity } \\
\text { (D) }\end{array}$ & $\begin{array}{c}\text { Total } \\
\text { Electric- } \\
\text { fed Non- } \\
\text { medical \& } \\
\text { Medical } \\
\text { Appliances } \\
\text { in Use } \\
\text { Before } \\
\text { Connection } \\
\text { to Grid } \\
\text { Electricity } \\
\text { (A+C) }\end{array}$ & $\begin{array}{l}\text { Total } \\
\text { Electric- } \\
\text { fed Non- } \\
\text { medical \& } \\
\text { Medical } \\
\text { Appliances } \\
\text { in Use } \\
\text { After } \\
\text { Connection } \\
\text { to Grid } \\
\text { Electricity } \\
\text { (B+D) }\end{array}$ \\
\hline Physiotherapy clinic & - & 5 & - & 3 & - & 8 \\
\hline Total & 291 & 407 & 12 & 40 & 303 & 447 \\
\hline
\end{tabular}

Table C: Statement on CAPEX \& REVEX of the Surveyed Healthcare Units

\begin{tabular}{|c|c|c|c|}
\hline Type of Organisation/ Firm & $\begin{array}{c}\text { Capital } \\
\text { Expenditure } \\
\text { Incurred Owing } \\
\text { to Grid } \\
\text { Electrification } \\
\text { (Estimated) }\end{array}$ & $\begin{array}{c}\text { Revenue } \\
\text { Expenditure- } \\
\text { Energy User } \\
\text { Charges Before } \\
\text { Grid Connection } \\
\text { PerMonth } \\
\text { (Estimated) }\end{array}$ & $\begin{array}{c}\text { Revenue } \\
\text { Expenditure- } \\
\text { Energy User } \\
\text { Charges After } \\
\text { Grid Connection } \\
\text { Per Month } \\
\text { (Estimated) }\end{array}$ \\
\hline Rural Block Hospital & $7,16,200$ & 30000 & 45000 \\
\hline Primary Healthcare Centre & 57,500 & 300 & 5000 \\
\hline Nursing Home & $1,80,000$ & 12000 & 17000 \\
\hline $\begin{array}{l}\text { Medical Store/ Druggist \& Chemist } \\
\text { Shops }\end{array}$ & $1,42,000$ & 3120 & 6180 \\
\hline Pathological Diagnostic Centre & $5,34,000$ & 1800 & 2500 \\
\hline ECG-cum-Medical Imaging Unit & 83,400 & 4267 & 3000 \\
\hline Physiotherapy Clinic & 41,000 & - & 1000 \\
\hline Total & $17,54,100$ & 51487 & 79680 \\
\hline
\end{tabular}

Journal of Rural Development, Vol. 36, No. 3, July-September : 2017 
Table D: Details of the Surveyed Healthcare Units in Sagar Island

\begin{tabular}{|c|c|c|c|c|c|}
\hline S. No. & $\begin{array}{l}\text { Name of the Gram } \\
\text { Panchayat }\end{array}$ & $\begin{array}{l}\text { Name of the } \\
\text { Respondent }\end{array}$ & $\begin{array}{l}\text { Profession/ } \\
\text { Designation } \\
\text { of the } \\
\text { Respondent in } \\
\text { the Organisa- } \\
\text { tion/ Firm }\end{array}$ & $\begin{array}{l}\text { Name of the } \\
\text { Organisation/ } \\
\text { Firm }\end{array}$ & $\begin{array}{l}\text { Type of } \\
\text { Organisation/ } \\
\text { Firm }\end{array}$ \\
\hline 1 & Rudranagar & Shri Animesh Maity & Proprietor & $\begin{array}{l}\text { Diganta } \\
\text { Diagnostic } \\
\text { Centre }\end{array}$ & $\begin{array}{l}\text { Pathological } \\
\text { Diagnostic } \\
\text { Centre }\end{array}$ \\
\hline 2 & Rudranagar & ShriSubrataJ ana & Employee & $\begin{array}{l}\text { Jana Medical } \\
\text { Hall }\end{array}$ & Medical shop \\
\hline 3 & Gangasagar & Dr. ManidipJana & $\begin{array}{l}\text { Medical Officer } \\
\text { In-charge }\end{array}$ & $\begin{array}{l}\text { Primary Health } \\
\text { Centre in } \\
\text { GangasagarGP }\end{array}$ & $\begin{array}{l}\text { Primary Health } \\
\text { Centre }\end{array}$ \\
\hline 4 & Rudranagar & Shri Dilip Kumar Giri & Radiographer & $\begin{array}{l}\text { Aragya } \\
\text { Diagnostic } \\
\text { Center }\end{array}$ & $\begin{array}{l}\text { Private ECG- } \\
\text { cum-Medical } \\
\text { Imaging Unit }\end{array}$ \\
\hline 5 & Rudranagar & Shri Sadhan Panigrahi & Employee & $\begin{array}{l}\text { New Guria } \\
\text { Medical }\end{array}$ & Medical Shop \\
\hline 6 & Rudranagar & $\begin{array}{l}\text { ShriSwapan Kumar } \\
\text { Das }\end{array}$ & Proprietor & $\begin{array}{l}\text { Rupam } \\
\text { Multi-speciality } \\
\text { Clinic }\end{array}$ & $\begin{array}{l}\text { Private } \\
\text { Pathological } \\
\text { Diagnostic } \\
\text { Centre }\end{array}$ \\
\hline 7 & Dablat & Shri BijoyDas & Proprietor & $\begin{array}{l}\text { Sandhya } \\
\text { Medical Shop }\end{array}$ & Medical Shop \\
\hline 8 & Rudranagar & Dr.Parimal Dakua & $\mathrm{BMOH}$ & $\begin{array}{l}\text { Sagar Rural } \\
\text { Block Hospital }\end{array}$ & Block Hospital \\
\hline 9 & Rudranagar & Shri Abhishek Maity & Proprietor & $\begin{array}{l}\text { Island Nursing } \\
\text { Home }\end{array}$ & Nursing Home \\
\hline 10 & Murigangall & Sk. Hapijul Kazi & Proprietor & $\begin{array}{l}\text { Sagar Medicine } \\
\text { Corner }\end{array}$ & Medical Shop \\
\hline 11 & Dablat & Shri Anup Kandar & Proprietor & $\begin{array}{l}\text { Kandar } \\
\text { Medicine }\end{array}$ & $\begin{array}{l}\text { Medical Shop- } \\
\text { cum-Private } \\
\text { Pathological } \\
\text { Diagnostic } \\
\text { Centre }\end{array}$ \\
\hline
\end{tabular}

Journal of Rural Development, Vol. 36, No. 3, July-September : 2017 


\begin{tabular}{|c|c|c|c|c|c|}
\hline S. No & $\begin{array}{l}\text { Name of the Gram } \\
\text { Panchayat }\end{array}$ & $\begin{array}{l}\text { Name of the } \\
\text { Respondent }\end{array}$ & $\begin{array}{l}\text { Profession/ } \\
\text { Designation } \\
\text { of the } \\
\text { Respondent in } \\
\text { the Organisa- } \\
\text { tion/ Firm }\end{array}$ & $\begin{array}{l}\text { Name of the } \\
\text { Organisation/ } \\
\text { Firm }\end{array}$ & $\begin{array}{l}\text { Type of } \\
\text { Organisation/ } \\
\text { Firm }\end{array}$ \\
\hline 12 & Murigangal & ShriTarun Kumar Paul & $\begin{array}{l}\text { Rural Health } \\
\text { Assitant }\end{array}$ & $\begin{array}{l}\text { Primary Health } \\
\text { Centre in } \\
\text { Muriganga-I } \\
\text { GP }\end{array}$ & $\begin{array}{l}\text { Primary Health } \\
\text { Centre }\end{array}$ \\
\hline 13 & $\begin{array}{l}\text { Dasparasumati- } \\
\text { nagarl }\end{array}$ & Shri Ashok Barik & Pharmacist & $\begin{array}{l}\text { Primary Health } \\
\text { Centre in } \\
\text { Dasparasumati } \\
\text { nagar I GP }\end{array}$ & $\begin{array}{l}\text { Primary Health } \\
\text { Centre }\end{array}$ \\
\hline 14 & Ramkarchar & Shri Niranjan Mal & $\begin{array}{l}\text { Partner of the } \\
\text { Establishment }\end{array}$ & $\begin{array}{l}\text { MaSumitra } \\
\text { Medical Hall }\end{array}$ & Medical Shop \\
\hline 15 & Dablat & ShriSibsahankarDas & $\begin{array}{l}\text { Partner of the } \\
\text { Establishment }\end{array}$ & $\begin{array}{l}\text { Kandar } \\
\text { Medicine } \\
\text { Shop }\end{array}$ & Medical Shop \\
\hline 16 & $\begin{array}{l}\text { Dasparasumati- } \\
\text { nagar II }\end{array}$ & Dr.Bishnupada Das & Proprietor & $\begin{array}{l}\text { Kumudini } \\
\text { Medical Hall }\end{array}$ & $\begin{array}{l}\text { Medical Shop- } \\
\text { cum-Private } \\
\text { ECG-cum- } \\
\text { Medical } \\
\text { Imaging Unit }\end{array}$ \\
\hline 17 & Rudranagar & $\begin{array}{l}\text { ShriSovan } \\
\text { SubhraDas }\end{array}$ & Proprietor & Physio-clinic & $\begin{array}{l}\text { Physio Therapy } \\
\text { Clinic }\end{array}$ \\
\hline
\end{tabular}

